\title{
UPAYA OPTIMALISASI MUTU PEMBELAJARAN DENGAN ADAPTASI STRATEGI SUPERVISI AKADEMIK DI TENGAH PANDEMI COVID-19
}

\author{
Romi Satria Azhar
}

Institut Agama Islam Negeri Curup

romisatria080392@gmail.com

Jumira Warlizasusi Nurman

Institut Agama Islam Negeri Curup

jumira.ifnaldi@gmail.com

\section{Rona Putra Azhar \\ Institut Agama Islam Negeri Curup \\ ronaputra@iaincurup.ac.id}

\begin{abstract}
ABSTRAK
Supervisor berperan penting dalam mengawal mutu pendidikan dengan tugas untuk memastikan bahwa proses pembelajaran berjalan sesuai standar nasional pendidikan. Disamping itu membantu, membimbing dan mengarahkan guru dalam meningkatkan kualitas pembelajaran. Supervisi akademik oleh kepala sekolah berorientasi pada bimbingan terhadap guru melalui diskusi dan pengarahan bersama guru sehingga dalam pelaksanaan supervisi pengajaran mengikuti tahapan yaitu perencanaan awal, pelaksanaan observasi dan tahap akhir. Tujuan penelitian ini untuk mengungkapkan kegiatan supervisi dan penguasaan kompetensi SMK oleh peserta didik serta adaptasi strategis pada proses supervisi sehingga berpengaruh pada optimalisasi mutu pembelajaran dalam menghadapi tantangan perubahan. Penelitian ini adalah penelitian deskriptif dengan menggunakan pendekatan kualitatif, yang menjadi objek peneltian adalah kegiatan supervisi di SMKIT Khoiru Ummah dimasa Pandemi Covid-19. Dari hasil penelitaan ini ditemukan bahwa pentingnya kegiatan supervisi dan strategi adaptasi terutama dimasa pandemi Covid-19, pentingnya pembinaan oleh kepala sekolah sebagai kegiatan supervisi guna saling mendukung peningkatan kinerja dan keterampilan guru guna mengoptimalkan mutu pembelajaran. Kegiatan supervisi secara berkala dan adanya strategi adaptasi supervisi baik dari media pembelajaran maupun evaluasi hasil pembelajaran upaya mengoptimalkan mutu pembelajaran.
\end{abstract}

Kata kunci: supervisi, mutu pembelajaran, strategi

\section{ABSTRACT}

Supervisors play an important role in safeguarding the quality of education, he is tasked with ensuring that the learning process runs according to national education standards, in addition, he is in charge of assisting, guiding and directing 
teachers in improving the quality of learning. Academic supervision by the principal is oriented towards guidance to teachers through compromise and discussion with the teacher so that in the implementation of this teaching supervision follows the stages, namely initial planning, implementing observations, and the final stage. The importance of supervision and mastery of SMK competencies by students as well as strategic adaptation to the supervision process so that it affects the optimization of the quality of learning in facing the challenges of change. This research is a descriptive study using a qualitative approach, the object of this research is the supervision activity at SMKIT Khoiru Ummah during the Pandemic Covid-19. From the results of this study it was found that the importance of supervision activities and adaptation strategies, especially during the pandemic Covid-19, the importance of coaching by the principal as a supervisory activity in order to mutually support the improvement of teacher performance and skills in order to optimize the quality of learning. Regular supervision activities and the existence of a strategy for adapting supervision both from learning media and evaluating learning outcomes in an effort to optimize the quality of learning.

Key words: supervision, quality of learning, strategy

\section{PENDAHULUAN}

Bergulirnya Era Revolusi 4.0 menyebabkaan terjadi perubahan struktur sosial yang sangat cepat, interaksi sosial bergantung pada teknologi, hilangnya beberapa jenis pekerjaan, arus informasi yang tidak terbendung sehingga masyarakat dituntut untuk bersaing dan tangguh dalam menghadapi perubahan ini (Sherly et al., 2020). Setiap lini kehidupan, baik ekonomi, politik, sosial, dan pendidikan mengalami pergeseran yang berdampak positif ataupun negatif yang mengharuskan kita beradaptasi dengan perubahan itu atau kita akan ditinggalkan oleh kemajuan. Begitu juga dengan pendidikan, arus informasi yang tak terbendung yang bisa memberikan pencerahan bagi peserta didik atau melemahkan perkembangan peserta didik. Yang perlu dipertimbangkan agar pendidikan mampu bertahan ditengah arus ini yaitu dengan tersedianya lembaga pendidikan yang dapat membentuk generasi kreatif, inovatif, serta kompetitif. Hal tersebut dapat dicapai salah satunya dengan cara mengoptimalisasi penggunaan teknologi sebagai alat bantu pendidikan yang diharapkan mampu menghasilkan output yang dapat mengikuti atau mengubah zaman menjadi lebih baik (Lase, 2019).

Respon atas perubahan pada Era Revousi 4.0, maka lembaga pendidikan dituntut untuk mampu memberikan pembelajaran sesuai kebutuhan siswa, pengunaan tes formatif, menjadikan guru sebagai mentor, memiliki pandangan bahwa adanya perbedaan kondisi peserta didik dan penyikapan yang harus sesuai potensi atau talenta masing-masing itu. Dalam proses pendidikan juga perlu adanya program untuk mendukung terwujudnya pendidikan cerdas melalui peningkatan dan pemerataan kualitas pendidikan, perluasan akses dan relevansi pemanfaatan teknologi sehingga menghasilkan keterampilan kolaborasi, komunikasi, berpikir kritis dan kreatif. Kebutuhan utama yang ingin dicapai dalam sistem pendidikan atau lebih khusus dalam metode pembelajaran yaitu siswa 
atau peserta didik memiliki penguasaan terhadap literasi baru. Literasi baru tersebut yaitu literasi data dan literasi teknologi (Yamin \& Syahrir, 2020).

Beberapa karakteristik pendidikan pada era ini yakni, pertama, belajar pada waktu dan tempat yang berbeda (e-learning) dengan memfasilitasi model pembelajaran jarak jauh dan mandiri. Kedua, pembelajaran individual dimana siswa akan belajar dengan peralatan belajar yang adaptif dengan kemampuannya. Ini menunjukkan bahwa siswa pada level yang lebih tinggi ditantang dengan tugas dan pertanyaan yang lebih sulit setelah melewati derajat kompetensi tertentu (Lase, 2019).

Upaya pemerintah dalam peningkatan kualitas sumber daya manusia melalui Menteri Pendidikan dan Kebudayaan dengan menerapkan program Pendidikan Merdeka Belajar yang dilandasi tanggung jawab untuk menjalankan amanat Pembukaan UUD 1945 alinea IV dalam rangka mencerdaskan kehidupan bangsa. Pasal 31 ayat 3 yang menyatakan bahwa pemerintah mengusahakan dan menyelenggarakan suatu sistem pendidikan nasional dalam rangka mencerdaskan kehidupan pendidikan bangsa. UU Sisdiknas Tahun 2003, bahwa sistem pendidikan nasional harus mampu menjamin pemerataan kesempatan pendidikan, peningkatan mutu serta relevansi dan efisiensi manajemen pendidikan untuk menghadapi tantangan sesuai dengan tuntutan perubahan kehidupan lokal, nasional dan global sehingga perlu dilakukan pembaharuan pendidikan secara terencana, terarah dan berkesinambungan. UU Sisdiknas Tahun 2003 Pasal 3 menyebutkan bahwa pendidikan nasional berfungsi mengembangkan kemampuan dan membentuk watak serta peradaban bangsa yang bermartabat dalam rangka mencerdaskan kehidupan bangsa, bertujuan untuk berkembangnya potensi peserta didik agar menjadi manusia yang beriman dan bertakwa kepada Tuhan Yang Maha Esa, berakhlak mulia, sehat, berilmu, cakap, kreatif mandiri dan menjadi warga negara yang demokratis serta bertanggung jawab. Nawacita kelima untuk meningkatkan kualitas hidup manusia Indonesia (Sherly et al., 2020). Merdeka Belajar merupakan respon terhadap kebutuhan sistem pendidikan pada Era Revolusi Industri 4.0 yang tetap mengutamakan juga pendidikan karakter (Lase, 2019).

Tantangan lain dari pendidikan nasional adalah pandemi Covid-19 yang masih mendera memberikan kita kesadaran akan pentingnya menyiapkan strategi yang komperhensif, dalam proses pembelajaran yaitu penerapan metode-metode adaptif sebagai respon akan kondisi dan tuntutan perubahan. Pandemi Covid-19 telah melumpuhkan berbagai sektor termasuk yang terdampak adalah sektor pendidikan. Aktifitas pendidikan dilakukan di rumah (School From Home) diharapkan menjadi solusi terbaik agar aktifitas pendidikan terus berjalan (Saleh, 2020). Metode pembelajaran baru yang dilakukan oleh siswa dan guru yaitu pembelajaran online, siswa terkadang terkendala pada komunikasi dan sosialisasi yang terbatas di antara siswa dan gurunya, tantangan yang lebih tinggi bagi siswa dengan kebutuhan pendidikan khusus, dan pada siswa dengan waktu penyaringan pelajaran yang lebih lama. Bagi orang tua, mereka menilai masalah terkait metode baru ini yaitu dengan kurangnya disiplin belajar siswa di rumah, dan banyaknya waktu mereka yang dihabiskan untuk membantu belajar anak-anak di rumah terutama untuk anak-anak tingkat dasar, kurangnya keterampilan teknologi, dan tagihan internet yang lebih tinggi akibat penerapan metode ini (Setyorini, 2020). 
Tenaga pengajar atau guru sebagai pendidik dalam melaksanakan fungsi dan tugasnya, mendapatkan tantangan yang juga kompleks, selain kualifikasi persyaratan sebagaimana tercantum dalam Undang-undang Sisdiknas Nomor 20 Tahun 2003 Pasal 39 bahwa tenaga kependidikan bertugas melaksanakan administrasi, pengelolaan, pengembangan, pengawasan, dan pelayanan teknis untuk menunjang proses pendidikan pada satuan pendidikan. Pendidik merupakan tenaga profesional yang bertugas merencanakan, dan melaksanakan proses pembelajaran, menilai hasil pembelajaran, melakukan pembimbingan dan pelatihan, serta melakukan penelitian dan pengabdian kepada masyarakat (Karyati, 2018).

Pada lembaga pendidikan kejuruan, tantangan yang dihadapi pun semakin kompleks, selain tantangan diatas, penguasaan kompetensi bidang kejuruan oleh peserta didik sebagai fungsi dari pendidikan kejuruan pun harus diperhatikan. Instruksi Presiden Nomor 9 Tahun 2016 tentang Revitalisasi Sekolah Menengah Kejuruan (SMK) sebagai acuan penyiapan pendidikan kejuruan dalam memasuki kompetisi global dan juga Perturan Menteri Perindustrian Nomor 3 Tahun 2017 tentang Pedoman Pembinaan dan Pengembangan SMK Berbasis Kompetensi yang link and match dengan industri memberikan dorongan kuat pentingnya peningkatan mutu pendidikan (Yusro, 2018).

Salah satu upaya peningkatan mutu pembelajaran yaitu dengan mengoptimalkan kinerja guru sebagai pendidik dengan pelaksanaan supervisi akademik. Kegiatan supervisi bertujuan untuk memberikan bantuan, bimbingan dan pembinaan kepada guru agar mereka mampu bekerja lebih baik dalam membimbing peserta didik serta dapat memperbaiki kinerjanya dalam meningkatkan pembelajaran di sekolah (Ajasan et al., 2016). Kepala sekolah sebagai supervisor harus mampu melaksanakan tugasnya karena supervisi kepala sekolah menduduki posisi yang sangat strategis di dalam upaya pencapaian keberhasilan suatu sekolah karena perannya sebagai pemimpin pendidikan, adminitrator pendidikan dan juga supervisor pendidikan yang turut menetukan efektifitas dan efisiensi penyelenggaraan pendidikan (Lazaruth, 1996).

Supervisi akademik oleh kepala sekolah berorientasi pada bimbingan terhadap guru melalui kompromi dan diskusi bersama guru sehingga dalam pelaksanaan supervisi pengajaran ini mengikuti tahapan, yaitu perencanaan awal, pelaksanaan observasi, dan tahap akhir (Wahidah, 2015). Pentingnya kemampuan kepala sekolah dalam membina sekolah, mensinergikan semua SDM untuk berkerja secara optimal serta mengkompromikan temua-temuan supervisi pada pihak terkait seperti yayasan pada penyelenggaraan pendidikan swasta sehingga terlaksana praktek pendidikan terbaik, adanya pengembangan arah pelayanan sekolah, memberikan peningkatan prestasi guru dan siswa baik lewat teknologi informasi atau sarana prasarana yang diperlukan oleh sekolah sebagai sebuah institusi, dan juga sebagai dukungan pada proses kegiatan pembelajaran yang kreatif dan menarik di sekolah (Sumarni, 2018).

Kepala sekolah sebagai agen supervisor dalam upaya peningkatan mutu pembelajaran perlu menetapkan objek, mendeskripsikan tujuan, mengidentifikasi kebutuhan, menetapkan indikator yang tepat, menentukan instrumen, melaksanakan, dan menindaklanjuti yang dikolaborasikan dan diintegrasikan 
melalui observasi, keterampilan manajerial, menggunakan teknik individu atau teknik kelompok, keterampilan penilaian dan evaluasi, dan keterampilan komunikasi (Muttaqin, 2020). Maka hubungan antara kontribusi supervisi kepala madrasah dan motivasi kerja guru terhadap kinerja mengajar guru sangat erat (Effendi et al., 2020). Sehingga supervisor harus memiliki kompetensi diantaranya merencanakan program supervisi akademik dalam rangka peningkatan profesionalisme guru, melaksanakan supervisi akademik terhadap guru dengan menggunakan pendekatan dan teknik supervisi yang tepat, menindak lanjuti hasil supervisi akademik terhadap guru dalam rangka peningkatan profesionalisme guru. Pengecekan secara berkala, observasi dan diskusi mendalam merupakan salah satu solusi dalam melaksanakan supervisi di masa pandemi Covid-19 (Elfidawati, 2020).

Adapun peneiltian yang relevan dengan topik penelitian ini adalah penelitian dari Elfidawati (2020) yang menyatakan bahwa pengecekan secara berkala, observasi dan diskusi mendalam merupakan salah satu solusi dalam melaksanakan supervisi di masa pandemi Covid-19 untuk peningkatan disiplin dan mutu pembelajaran, namun yang menjadi objek adalah siswa SD, belum membahas tentang kegiatan supervisi akademis di SMK yang meliputi pelajaran kejuruan dan prakteknya.

Wahidah (2015) dalam penelitiannya memaparkan bahwa supervisi sangat efektif bagi peningkatan mutu, namun belum mempertimbangkan aspek pandemic Covid-19 dan pentingnya revitalisasi SMK pada era revolusi industri 4.0. Sedangkan Muttaqin (2020) dalam penelitiannya memaparkan bahwa manajemen supervisi merupakan mekanisme kendali mutu yang penting untuk menjamin mutu pendidikan, dan telah memaparkan tahapan supervisi namun belum memuat strategi supervisi ditengah pandemi serta adaptasi dengan teknologi sebagai akibat dari Era Revolusi Industri 4.0.

Penelitian lain memaparkan bahwa supervisi akademik yang diterapkan kepala sekolah sangat efektif guna memberikan bantuan, bimbingan dan pembinaan kepada guru agar mereka mampu bekerja lebih baik dalam membimbing peserta didik serta dapat memperbaiki kinerjanya dalam meningkatkan pembelajaran di sekolah. Namun aspek strategi supervisi sebagai respon dari pandemic Covid-19 belum dijabarkan karena peneltian dilakukan sebelum pandemic Covid-19 melanda (Ajasan et al., 2016).

Selain itu pelaksanaan supervisi akademik oleh pengawas sekolah dapat mengubah kesadaran guru untuk meningkatkan kemampuan profesionalnya, namaun dalam penelitian ini belum menjelaskan adaptasi strategi dimasa pandemi Covid-19 (Messi et al., 2018). Dan penelitian lain menjelaskan bahwa peran supervisor memberikan petunjuk teknik dan strategi terhadap langkahlangkah dan perilaku guru yang harus dilakukan dalam proses pembelajaran sehingga prestasi peserta didik meningkat dan meningkatnya prestasi peserta didik merupakan wujud peningkatan mutu pembelajaran guru, namun penelitian ini belum menjelaskan tentang penguasan kompetensi kejuruan, adaptasi strategi pada masa pandemi Covid-19 walau telah menguraikan supervisi sebagai upaya optimaisasi mutu pembelajaran (Sutrisno, 2018).

Oleh karena itu penelitian ini memiliki tujuan untuk mengetahui proses dan teknik supervise, mutu pembelajaran dan upaya-upaya optimalisasi mutu 
pembelajaran dengan adaptasi strategi supervisi ditengah pandemi di SMK IT khoiru Ummah.

\section{METODE}

Penelitian ini adalah penelitian deskriptif dengan menggunakan pendekatan kualitatif yaitu pendekatan penelitian yang digunakan untuk mendapatkan data mendalam, suatu data yang mengandung makna (Sugiyono, 2017), secara holistic dan cara deskriptif dalam bentuk kata-kata dan bahasa pada suatu konteks khusus yang alamiah (Moleong, 2011). Pada pendekatan ini, peneliti akan berusaha mengeksplorasi data-data terkait tentang objek penelitian yang berangkat dari data yang ada, memanfaatkan teori sebagai bahan penjelas dan berakhir pada sebuah teori (Sugiyono, 2017).

Penelitian ini dilaksanakan di SMK IT Khoiru Ummah. Yang menjadi objek penelitiannya adalah situasi sosial (social situation) yaitu peneliti mengamati secara mendalam aktivitas (activity), orang-orang (actors), dan tempat (place) tertentu dengan peneliti sebagai instrumen utama penelitian (Sugiyono, 2017). Selain peneliti sebagai instrumen maka peneliti nanti akan membuat instrumen sederhana guna melengkapi data yang dibutuhkan saat penelitian, bisa berupa angket, wawancara terstruktur atau observasi terstruktur. Jenis data yang akan digunakan meliputi data kualitatif yaitu kata, skema atau gambar yang didapat dari hasil pengumpulan data melalui tehnik pengumpulan data. Dan bisa berupa data kuantitatif yaitu data yang berbentuk angka hasil penghitungan statistik atau dokumentasi data oleh peneliti pada subjek penelitian. Sumber data yang digunakan meliputi, sumber data primer yaitu sumber data yang langsung memberikan data tentang objek penelitian kepada peneliti (Sugiyono, 2017).

Peneliti berusaha mengeksplorasi data dari objek penelitian secara alamiah baik sumber data primer meliputi kepala sekolah, dewan guru dan pihak terkait maupun data sekunder di lingkungan SMK IT Khoiru Ummah dengan teknik wawancara dan observasi. Kegiatan analisis dilakukan saat pengumpulan data berlangsung dan setelah selesai pengumpulan data dalam periode tertentu. Aktifitas dalam analisis data kualitatif dilakukan secara interaktif dan terusmenerus sampai tuntas, sehingga datanya sudah jemu. Aktivitas analisis data meliputi data reduction, data display dan conclusion drawing. Penelitian ini mencari dan menyusun data dari informan.

\section{HASIL DAN PEMBAHASAN}

\section{Proses dan Teknik Supervisi di SMK IT Khoiru Ummah.}

Proses pelaksanaan supervisi akademik dilakukan oleh Kepala Sekolah dalam suatu siklus yang terdiri dari tiga tahap, yaitu pertama tahap perencanaan awal, kedua tahap pelaksanaan observasi, dan ketiga tahap akhir (diskusi balikan). Kepala Sekolah SMK IT Khoiru Ummah, bapak Rajab Efendi, S.Pd, S,Pd,I melakukan fungsinya sebagai supervisor dalam rangka peningkatan kinerja guru maka dalam proses supervisi, kepala sekolah menilai kualitas pembelajaran dari kesiapan guru, RPP, media pembelajaran dan lain-lain yang terangkum dalam indikator instrumen observasi. Hal ini senada dengan penelitian Wahidah (2015) bahwa dalam proses supervisi haruslah sitematis, objektif dalam pengertian ada data yang didapat berdasarkan observasi, serta 
menggunakan alat pencatat sehingga terkumpul informasi sebagai hasil proses supervisi di kelas.

Pada masa pandemic Covid-19, strategi adaptasi supervisi oleh kepala sekolah dilakukan dengan media yaitu berupa Google Form, media WhatsApps serta dengan aplikasi zoom meeting, tergantung kondisi serta aspek-aspek yang akan di supervise. Supervisi di masa pandemi Covid-19 selain melalui observasi juga perlu dilakukan dengan menggunakan teknik diskusi mendalam dengan guru yang bersangkutan. Hal ini sejalan dengan penelitian Elfidawati (2020) bahwa kegiatan pengecekan secara berkala, observasi dan diskusi mendalam menjadi strategi adaptif dalam pelaksanaan supervisi di masa pandemi Covid19.

Pada tiga bulan pertama pandemi, dan instruksi Dinas Pendidikan daerah setempat tentang kegiatan belajar di rumah (school from home) maka kegiatan pembelajaran diupayakan dengan pengunaan pembelajaran daring. Maka strategi supervisi dilakuan dalam bentuk gooegle form, kefektifan pembelajaran serta pematauan oleh kepala sekolah dalam bentuk keikutsertaan kepala sekolah dalam grup WhatsApps guru dan siswa sehingga bisa menjadi media supervisi sebagai upaya adaptasi strategi supervisi guna mengoptimalkan mutu pembelajaran. Hasil supervisi melalui media WhatsApps ini memberikan gambaran sebagai acuan pembinaan keterampilan penguasaan teknologi serta pentingnya kegiatan supervisi dengan teknik individu, teknik kelompok ataupun supervisi klinis. Hal ini sejalan dengan penelitian lain yang menerangkan bahwa unsur utama dari pelaksanaan supervisi yaitu pembinaan yang dilakukan kepala sekolah kepada semua guru di sekolah binaannya terfokusnya adalah menilai, mengkaji, meningkatkan, memperbaiki dan mengembangkan mutu kegiatan belajar mengajar yang dilakukan guru melalui pendekatan bimbingan dan konsultasi dalam nuansa dialog professional terutama kepada guru-guru, baik secara individu maupun secara kelompok dalam usaha memperbaiki kualitas proses dan hasil pembelajaran (Messi et al., 2018).

Teknik supervisi pengajaran oleh kepala sekolah berdasarkan hasil penelitian ini dilakukan oleh kepala sekolah adalah teknik individu, dan teknik kelompok. Secara garis besar cara atau teknik supervisi dapat digolongkan menjadi dua, yaitu teknik perseorangan dan teknik kelompok (Purwanto, 2005). Disamping itu juga kepala sekolah melakukan supervisi klinis yang difokuskan pada peningkatan mutu pembelajaran dengan melalui siklus yang sistematik, dalam perencanaan, pengamatan (pelaksanaan) serta analisis yang intensif dan cermat tentang penampilan mengajar guru.

Teknik dan proses pelaksanaan supervisi akademik kepala sekolah SMK IT Khoiru Ummah sudah efektif, yaitu sudah mempergunakan teknik individu dan kelompok sesuai kondisi yang disesuaikan dengan kebutuhan dan kondisi SMK IT Khoiru Ummah dengan mempergunakan pendekatan prinsip praktis, sistematis, objektif, realistis, antisipatif, konstruktif, kooperatif, kekeluargaan, demokratis, aktif, humanis, berkesinambungan, terpadu, komprehensif. sudah melaksanakan secara efektif. Adapun waktu pelaksanaan supervisi yang dilaksanakan setiap awal semester ganjil dan genap, sedangkan untuk monitoring dilakukan secara rutin monitoring kegiatan KBM sudah dapat dilaksanakan setiap hari kegiatan pembelajaran yaitu dengan media WhatsApps, gooegle form atau aplikasi zoom meeting. 
Kepala sekolah sudah efektif dalam peningkatan kualitas pembelajaran di SMK IT Khoiru Ummah. Hal tersebut dapat ditinjau dari pelaksanaan supervisi, pemberian bantuan dari kepala sekolah kepada para guru, menampung setiap persoalan masalah yang ditemui/dihadapi oleh para guru dalam proses pengajaran untuk dapat menemukan strategi dari pemecahan masalah yang ada.

\section{Kualitas Mutu Pembelajaran di SMK IT Khoiru Ummah pada Masa Pandemi Covid-19.}

Upaya optimalisasi mutu pembelajaran, maka kegiatan supervisi menyangkut pelaksanaan KBM diarahkan pada pengelolaan kelas mulai dari kegiatan membuka, kegiatan inti, dan evaluasi pembelajaran tindak lanjut. Kegiatan supervisi oleh kepala sekolah dimulai dengan penentuan materi supervisi, yakni terdiri dari perencanaan program supervisi yang berkaitan dengan administrasi guru sepeti program tahunan, program semester, silabus, Rencana Pelaksanaan Pembelajaran (RPP), kalender pendidikan, jadwal tatap muka, agenda harian, daftar nilai, Kriteria Ketuntasan Maksimal (KKM), dan absensi siswa.

Pada masa pandemi Covid-19 sebagai mana diungkapkan kepala sekolah SMK IT Khoiru Ummah upaya optimalisasi mutu pembelajaran dilakukan dengan adaptasi strategi supervisi karena adanya perubahan metode dan media serta waktu pembelajaran. Kepala sekolah berkesimpulan bahwa mutu pembelajaran yang dilakukan oleh guru di SMK IT Khoiru Ummah tidak mengalami penurunan yang berarti karena kegiatan supervisi secara berkala dilakukan selain supervisi rutin per tiga bulan.

Supervisor melakukan pemantauan serangkaian kegiatan guna membantu guru mengembangkan kemampuannya mengelola proses pembelajaran untuk mencapai tujuan pembelajaran. Kegiatan pembelajaran mengikuti Surat Edaran Pemerintah Daerah Rejang Lebong melalui Dinas Pendidikan dan Kebudayaan yang meliputi instruksi kegiatan non tatap muka yaitu school from home, guna menahan laju perkembangan Covid-19. Kegiatan pembelajaran daring membutuhkan keterampilan para guru maka kepala sekolah selaku supervisor melakukan supervisi dengan beradaptasi pada media pembelajaran yang dilakukan guru, seperti pengunaan google form, WhatApps ataupun aplikasi zoom meeting. Guna mengoptimalkan mutu pembelajaran, dilakukan pembinaan yang merupakan tindak lanjut hasil supervisi yaitu dilakukan pembekalan penguasaan teknologi seperti pengunaan aplikasi serta perangkat lunak lainnya, kemampuan komunikasi dengan media, kemapuan menampilakan slide, kemampuan menghasilkan video pembelajaran yang menarik sampai menerapkan evaluasi berbasis digital.

Pada prinsipnya perencanaan program supervisi akademik meliputi, objektifitas (data apa adanya) maka kegiatan supervisi di SMK IT Khoiru Ummah oleh kepala sekolah dan di bantu wakil kepala sekolah bidang kurikulum serta dari teman sejawat menghasilkan data yang akurat tentang keterampilan guru guna menunjang proses pembelajaran. Kepala sekolah sebagai supervisor harus memiliki tanggung jawab pengawasan dan pembinaan keterampilan guru sehingga mutu pembelajaran optimal dan perlu kegiatan berkelanjutan sehingga upaya optimalisasi mutu pembelajaran mengacu pada perkembangan keterampilan guru, pengunaan media dan perkembangan instruksi pemerintah 
daerah tentang kebijakan pembelajaran di masa pandemi Covid-19 dengan tetap mengacu pada Standar Nasional Pendidikan, kebutuhan dan kondisi sekolah/madrasah.

Guna mengoptimalkan pembelajaran dengan strategi supervisi maka supervisor melaksanakan supervisi akademik terhadap guru, harus menggunakan pendekatan dan teknik supervisi yang tepat. Serta perlunya kesiapan perlengkapan supervisi, instrumen, sesuai dengan tujuan dan sasaran, objek metode, teknik, dan pendekatan yang direncanakan, dan instrumen yang sesuai. Kepala sekolah harus memiliki ketrampilan teknikal berupa kemampuan menerapkan teknik-teknik supervisi yang tepat. Kepala sekolah dalam proses supervisi melakukan pemetaan permasalahan, karena dalam pembelajaran di SMK IT Khoiru Ummah menuntut adanya pengusaan kompetensi kejuruan, maka pada tiga bulan pertama, kegiatan pembelajaran dilakukan full daring, maka teknik, metode serta pendekatan supervisi pun beradaptasi dengan kondisi itu, sehingga proses pembelajaran diarahkan pada media visualisai. Kepala sekolah mengarahkan dalam kegiatan pembinaan dalam proses pembiasaan baru era new normal maka praktek diprioritaskan untuk melihat video-video praktek teknis kejuruan.

Tindak lanjut hasil supervisi akademik dalam rangka optimalisasi mutu pembelajaran dengan adaptasi strategi supervisi di sekolah sudah cukup baik di SMK IT Khoiru Ummah, hal ini ditandai dengan adanya dokumen pelaksanaan yang tersusun rapi. Efektitas materi ditunjukkan dengan dipergunakannya materi supervisi akademik meliputi materi pedagogik, dan profesionalisme guru dari penelitian dokumen adminitrasi pembelajaran yang terinci dari persiapan, pelaksanaan, penilaian, evaluasi dan tindak lanjut pembelajaran guru, sampai dengan instrumen pengamatan pelaksanaan pembelajaran guru dalam proses pembelajaran kelas. Optimalnya mutu pembelajaran ditandai dengan hasil evaluasi pembelajaran yang dilakukan oleh guru dan supervisi tentang hasil evaluasi pembelajaran. Dari hasil evaluasi pembelajaran, siswa mampu menguasi Kompetensi Dasar yang harus dicapai dalam satuan pembelajaran pada tingkat tertentu walau adanya beberapa kompetensi yang minim fasilitas visualisasinya.

Pelaksanaan supervisi akademik kepala sekolah sudah efektif dalam rangka upaya optimalisasi mutu pembelajaran. Hal tersebut dapat ditinjau dari pelaksanaan supervise. Teknik dan pendekatan pelaksanaan supervisi akademik kepala sekolah SMK IT Khoiru Ummah sudah efektif, yaitu sudah mempergunakan teknik individu dan kelompok sesuai kondisi yang disesuaikan dengan kebutuhan dan kondisi SMK IT Khoiru Ummah, sejalan dengan penelitian yang dilakukan oleh Muttaqin (2020) yang menemukan bahwa kegiatan supervisi dilakukan dengan menetapkan objek, mendeskripsikan tujuan, mengidentifikasi kebutuhan, menetapkan indikator yang tepat, menentukan instrumen, melaksanakan, dan menindaklanjuti.

\section{Upaya-Upaya Optimalisasi Mutu Pembelajaran dengan Adaptasi Strategi Supervisi di Tengah Pandemi di SMK IT Khoiru Ummah.}

Supervisi pembelajaran oleh kepala sekolah dilakukan untuk pembinaan guru dalam rangka meningkatkan kinerja guru (Wahidah, 2015). Peningkatan kinerja guru didorong oleh keterampilan guru dalam menggunakan media 
pembelajaran terlebih ditengah pandemi, penguasaan teknologi sebagai media pembelajaran sangat diperlukan. Kepala sekolah selaku supervisor dalam upaya pembinaan guru dalam bidang keterampilan pengusaan teknologi sebagai upaya adaptasi kebiasaan baru sehingga mendorong upaya optimalisasi mutu pembelajaran yaitu dengan pembekalan keterampilan pengunaan media, baik pembekalan berupa arahan maupun pemberian aplikasi sampai pada cara pengunaannya.

Pelaksanaan supervisi akademik oleh kepala sekolah dapat mengubah kesadaran guru untuk meningkatkan kemampuan profesionalnya (Messi et al., 2018). Hal ini sesuai dengan dari hasil supervisi yang dilakukan kepala sekolah setelah pembekalan yaitu adanya peningkatan keterampilan guru, adanya keinginan untuk menambah pengetahuan serta keinginan memecahkan masalah dalam penguasaan teknologi dengan bertanya serta mencari informasi pada media lain seperti youtube atau layanan google sehingga upaya optimalisasi mutu pembelajaran disesuaikan dengan kondisi serta dikembangkan dengan keikutsertaan dalam pembinaan oleh kepala sekolah serta pengembangan diri secara individu.

Kegiatan supervisi pembelajaran bertujuan untuk meningkatkan kemampuan profesional guru dalam proses dan hasil pembelajaran melalui pemberian layanan professional (Masaong, 2013). Dalam penelitian ini terungkap bahwa kepala sekolah melakukan upaya supervisi dengan didahului oleh penguasaan kepala sekolah pada teknologi secara professional sehingga dalam proses supervisi, penggunaan media yang baru dalam proses pembelajaran serta evaluasi hasil pembelajar oleh guru maka kepala sekolah sebagai supervisor mampu menilai optimal atau tidaknya pengunaan media belajar, berhasilnya proses evaluasi pembelajaran dengan form digital yaitu google form atau dengan media Massage.

Pentingya peran kepala sekolah dalam kegiatan pembelajaran terutama pada pendidikan kejuruan yaitu penguasaan kompetensi kejuruan terutama dimasa pandemi Covid-19 yang menuntut setiap wraga sekolah mematuhi protokol kesehatan maka kepala sekolah melakukan program DATAMU ONE PRAKTEK yaitu setiap kelas kejuruan dilakukan kegiatan secara berkala dengan intensitas pertemuan dua kali teori dan sekali praktek dalam tiap minggunya. Peran supervisor memberikan petunjuk teknik dan strategi terhadap langkahlangkah dan perilaku guru yang harus dilakukan dalam proses pembelajaran sehingga prestasi peserta didik meningkat dan meningkatnya prestasi peserta didik merupakan wujud peningkatan mutu pembelajaran guru sebagaimana penelitian yang dilakukan oleh Sutrisno (2018).

\section{SIMPULAN}

Supervisor berperan penting dalam mengawal mutu pendidikan, ia bertugas untuk memastikan bahwa proses pembelajaran berjalan sesuai standar nasional pendidikan. Disamping itu, ia bertugas membantu, membimbing dan mengarahkan guru dalam meningkatkan kualitas pembelajaran. Supervisi akademik oleh kepala sekolah berorientasi pada bimbingan terhadap guru melalui kompromi dan diskusi bersama guru sehingga dalam pelaksanaan supervisi pengajaran ini mengikuti tahapan, yaitu perencanaan awal, pelaksanaan observasi, dan tahap akhir. Pentingnya kegiatan supervisi dan 
penguasaan kompetensi SMK oleh peserta didik serta adaptasi strategis pada proses supervisi sehingga berpengaruh pada optimalisasi mutu pembelajaran dalam menghadapi tantangan perubahan. Supervisor melakukan supervisi dengan beradaptasi pada media pembelajaran yang dilakukan guru, seperti pengunaan google form, WhatsApps ataupun aplikasi zoom meeting, maka guna mengoptimalkan mutu pembelajaran, dilakukan pembinaan yang merupakan tindak lanjut hasil supervisi yaitu dilakukan pembekalan penguasaan teknologi seperti pengunaan aplikasi serta perangkat lunak lainnya, kemampuan komunikasi dengan media, kemampuan menampilakan slide, kemampuan menghasilkan video pembelajaran yang menarik sampai menerapkan evaluasi berbasis digital.

Optimalnya mutu pembelajaran ditandai dengan hasil evaluasi pembelajaran yang dilakukan oleh guru dan supervisi tentang hasil evaluasi pembelajaran. Sebagai supervisor mampu menilai optimal atau tidaknya pengunaan media belajar, berhasilnya proses evaluasi pembelajaran dengan form digital yaitu google form atau dengan media Massag. Upaya adaptasi kebiasaan baru sehingga mendoroiong upaya optimalisasi mutu pembelajaran yaitu dengan pembekalan keterampilan pengunaan media, baik pembekalan berupa arahan maupun pemberian aplikasi sampai pada cara pengunaannya.

\section{REFERENSI}

Ajasan, A., Usman, N., \& Niswanto, N. (2016). Efektivitas Pelaksanaan

Supervisi Akademik Oleh Kepala Sekolah Dalam Meningkatkan Kinerja Guru Di Smk Negeri 1 Meulaboh. Jurnal Administrasi Pendidikan : Program Pascasarjana Unsyiah, 4(3), 1-9.

http://jurnal.unsyiah.ac.id/JAP/article/view/4795

Effendi, T., Ifnaldi, I., Yanto, M., \& Warlizasusi, J. (2020). Kontribusi Supervisi Kepala Madrasah dan Motivasi Kerja Guru Terhadap Kinerja Mengajar. Journal Of Administration and Educational Management (ALIGNMENT), 3(2), 233-243. https://doi.org/10.31539/alignment.v3i2.1448

Elfidawati, E. (2020). Peningkatan Kedisiplinan Dan Kualitas Pembelajaran Guru Pada Masa Pandemi Covid-19 Melalui Supervisi Akademik Di SD 009 Kuala Terusan Pangkalan Kerinci. Jurnal Kepemimpinan Dan Pengurusan Sekolah, 5(2), 171-179. https://doi.org/10.34125/kp.v5i2.564

Karyati, Y. (2018). Keefektifan Supervisi Akademik Kepala Sekolah Dalam Upaya Peningkatan Kualitas Pembelajaran Di SMK. Media Manajemen Pendidikan, 1(2), 157-168. https://doi.org/10.30738/mmp.v1i2.3111

Lase, D. (2019). Pendidikan di Era Revolusi Industri 4.0. SUNDERMANN: Jurnal IImiah Teologi, Pendidikan, Sains, Humaniora Dan Kebudayaan, 12(2), 28-43. https://doi.org/10.36588/sundermann.v1i1.18

Lazaruth, S. (1996). Tugas dan Tanggung Jawab Kepala Sekolah. Kanisius Media.

Masaong, A. K. (2013). Supervisi Pembelajaran dan Pengembangan Kapasitas Guru. Alfabeta.

Messi, M., Sari, W. A., \& Murniyati, M. (2018). Pelaksanaan Supervisi Akademik Pengawas Sekolah Sebagai Upaya Peningkatan Profesionalisme Guru. JMKS: Jurnal Manajemen, Kepemimpinan Dan Supervisi Pendidikan, 3(1), 114-125. https://doi.org/10.31851/jmksp.v3i1.1583 
Moleong, L. J. (2011). Metodologi Penelitian Kualitatif. Remaja Rosda Karya.

Muttaqin, I. (2020). Supervision Planning at Islamic Education Institutions: Google Scholar Library Studies and Mendeley's Reference Manager. ISTAWA: Jurnal Pendidikan Islam, 5(2), 222-238. https://doi.org/10.24269/ijpi.v5i2.2847

Purwanto, N. (2005). Administrasi dan Supervisi Pendidikan. Remaja Rosda Karya.

Saleh, M. (2020). Merdeka Belajar di Tengah Pandemi Covid-19. Prosiding Seminar Nasional Hardiknas, 51-56.

http://proceedings.ideaspublishing.co.id/index.php/hardiknas/article/view/8

Setyorini, I. (2020). Pandemi Covid-19 dan Online Learning: Apakah

Berpengaruh Terhadap Proses Pembelajaran Pada Kurikulum 13 ? Jiemar, 1(1b), 95-102. https://doi.org/10.7777/jiemar.v1i1.31

Sherly, S., Dharma, E., \& Sihombing, H. B. (2020). Merdeka Belajar: Kajian Literatur. Prosiding Konferensi Nasional Pendidikan, 1, 183-190.

http://proceeding.urbangreen.co.id/index.php/library/issue/view/konferensin asionalpendidikan1

Sugiyono. (2017). Metode Penelitian: Kuantitatif, Kualitatif, R\&D. CV. Alfabeta.

Sumarni, S. (2018). Peran dan Fungsi Yayasan Dalam Pengelolaan Pendidikan Madrasah. EDUKASI: Jurnal Penelitian Pendidikan Agama Dan

Keagamaan, 16(2), 218-231. https://doi.org/10.32729/edukasi.v16i2.490

Sutrisno. (2018). Implementasi Supervisi Akademik Mutu Pembelajaran

Pendidikan Agama Islam Di Sekolah Dasar Islam Terpadu (SD - IT)

Harapan Bunda Purwokerto [IAIN Purwokero].

http://repository.iainpurwokerto.ac.id/5144/

Wahidah, S. (2015). Pelaksanaan Supervisi Pengajaran Oleh Kepala Sekolah Dalam Meningkatkan Kinerja Guru Di SMK Negeri 1 Banda Aceh. Jurnal Administrasi Pendidikan : Program Pascasarjana Unsyiah, 3(3), 50-57. http://jurnal.unsyiah.ac.id/JAP/article/view/2530

Warits, A. (2015). Supervisi Pendidikan Islam (Studi atas Kontribusi Pengawas dalam Memotivasi dan Meningkatkan Profesionalisme Guru dalam Proses Pembelajaran di Sumenep). 'Anil Islam: Jurnal Kebudayaan Dan IImu Keislaman, 8(2), 149-176.

https://jurnal.instika.ac.id/index.php/Anillslam/article/view/41

Warlizasusi, J., Putra, H. R., Ifnaldi, I., Lukman, L., \& Dewinofrita, D. (2020). The Role of Collegial Supervision of School Supervisors and Head of Developing Teacher's Pedagogic Competence in Rejang Lebong Regency. International Journal of Innovation, Creativity and Change, 13(12), 948961.

https://www.ijicc.net/images/vol_13/lss_12/131283_Warlizasusi_2020_E_R .pdf

Yamin, M., \& Syahrir, S. (2020). Pembangunan Pendidikan Merdeka Belajar (Telaah Metode Pembelajaran). JIME: Jurnal IImiah Mandala Education, 6(1), 126-136. https://doi.org/10.36312/jime.v6i1.1121

Yusro, M. (2018). Strategi Peningkatan Mutu Akreditasi Sekolah Menengah Kejuruan (SMK) Memasuki Era Revolusi. Seminar Nasional APTEKINDO. http://aptekindo2018.conference.unesa.ac.id/prosiding-nasional-aptekindo2018/ 